\title{
A Case of Human Paragonimiasis and its Treatment
}

\author{
Mitsuru Shirakawa*
}

\begin{abstract}
1. Introduction
Pulmonary tuberculosis has not seldom been diagnosed erroneously on the basis of chest X-ray findings in patients with paragonimiasis ${ }^{1-4)}$. As a result, healing has often been retarded in such patients by antituberculotic and bloody therapies.

The author had an opportunity to examine a patient with this disease which occurred in Wakayama prefecture and was diagnosed erroneously as pulmonary tuberculosis on the basis of its chest X-ray findings and detected ova of Paragonimus by sputum and stool examinations. When this patient was subjected to detailed parasitological examination, treatment and chest X-ray examination and changes in these findings were observed, interesting results were obtained.
\end{abstract}

\section{Outlines of the case and treatment}

Patient name : Sai Ko Gyoku (female)

Birth date: September 2, 1924

Present address: Kibi-cho, Arita-gun, Wakayama Prefecture.

Legal domicile (birth place) : Sansando, Sanjomen, Gun-i-gun, Keisho Hokudo, Korea

Date of entry to Japan: August, 1940 (16 years in age). She moved to the present address with her parents.

Occupation: She is a housewife and engaged in bicycle keeping. Family and personal histories are unremarkable.

She is constitutionally strong and likes raw fish and crabs by nature. At the beginning of April in 1967, she visited her native place in Korea and stayed there for about 2 months, followed by coming back to her present address in Japan at the end of May. According to her, she ate raw freshwater fish (carp), but did not eat crabs during her 2 month stay in Korea.

During summer in the same year 2-3 months after her return to the present address, she noticed an egg-sized mass in the right hypochondriac region. This mass then moved to the left mammary region and she began to expectorate bloody sputum. On September 20, the underwent chest X-ray examination in a local hospital (photo 1) and was treated by antituberculotic therapy as a patient with pulmonary tuberculosis. The mass then moved to the lower abdomen and she complained of pain. She visited a public hospital and underwent surgical incision for suppuration. The mass moved further to the gluteal region, but disappeared within 2-3 days.

On October 28 in the same year, she visited an internal clinic in Wakayama City. The findings during the first examination in this clinic were as described below.

The patient was moderately developed and nourished. The visible mucosa and skin were normal. Anemia was not noted. In the chest, marked change was not noted on percussion and

* Department of Hygiene, Miyazaki Medical College (Director : Prof. Mitsuru Shirakawa) 
auscultation. In the abdomen, the liver and spieen were unpalpable. In the left gluteal region, a circular induration $5 \mathrm{~cm}$ in diameter was palpable, but redness, tenderness and subdermal adhesion were not noted and bulge of the skin was also absent. In the chest X-ray film brought with her (taken on September 20,1967) (Photo 1), there were shadows suggestive of pulmonary tuberculosis in the right middle lung field.

In the laboratory date during the first examination, chest $\mathrm{X}$-ray findings on this day (Photo 2) were almost identical with those of the film taken on September 20. The erythrocyte sedimentation rate was $46 \mathrm{~mm} /$ hour. Hematological values were St $4 \%$, Seg $41 \%$, Eos $34 \%$, Bas $0 \%$, Ly $21 \%$ and Mo $0 \%$.

This internal physician suspected parasitism in this patient, because antituberculotic therapy in the past was not effective and eosinocytes increased markedly in number. In order to deny pulmonary tuberculosis, the physician delivered her sputum specimens for the test for parasitic ova and smear culture for tubercle bacillus to the Clinical Examination Center established by the Wakayama City Medical Association. The results of several tests were all negative. The patient was not convinced of the results and did not appear for about 1 year. During this period, erythromycin was administered intermittently against coughing and sputum expectoration for several months as palliative treatment.

Additional tests for parasitic ova and tubercle bacillus were performed on November 8, 1967 and June 8,1968 , but the results were all negative.

The findings obtained by percussion and auscultation and chest X-ray examination (Photo 3 ) on June 1, 1968 when the patient appeared again were almost the same as those obtained previously. The erythrocyte sedimentation rate was $12 \mathrm{~mm}$ /hour. Hematological values were St $3 \%$, Seg $31 \%$, Eos $18 \%$, Bas $0 \%$, Ly $41 \%$ and Mo $7 \%$. The induration in the left gluteal region was still palpable.

On August 7,1968, this patient was referred for various tests to the author working at that time as a professor and director of the Department of Public Health, Wakayama Prefectural Medical College. Since the author had been informed of suspected parasitism of Gnathostoma spinigerum in a family of 5 members living in Wakayama City, this patient as well as these family members were examined on this day by intradermal test using the intradermal antigen for Gnathostoma spinigerum provided from Prof. Ichiro Miyazaki, Department of Parasitology, School of Medicine, Kyushu University. As a result, all of them showed negative reaction.

Accordingly, the author suspected strongly paragonimiasis in this patient and invited her to the author's laboratory on March 1, 1969. When sputum specimens brought with her were examined microscopically, many ova of paragonimus could be detected from the portion of bloody sputum. On March 5 in the same year, sputum and stool were tested again and presence of many ova of paragonimus could be confirmed in both of them. In addition, ova of Metagonimus yokogawai and Trichostrongylus orientalis could be found in the stool.

Ova of paragonimus in the sputum and those in the stool were as shown in Photo 4 and 5 , respectively.

\section{Outline of treatment and results}

Treatment and examinations were summarized in Table 1. For 3 weeks from March 8 to 28, 1969 as the first cycle of treatment, bithionol (sold as Bitin from Tanabe Pharmaceutical Co., Ltd.) with established efficacy for paragonimiasis was administered on alternate days in the dose of 8 tablets 1.6 . $\mathrm{g} /$ day on the basis of $30 \mathrm{mg} / \mathrm{kg}^{4-6}$. It was first planned to administer on alternate days for $1 \mathrm{month}$ (15 times), but the first cycle had to be discontinued after the 11th treatment (17.6g in total), because the patient complained of adverse reactions such as nausea and abdominal pain after the 11th treatment. 
881(65)

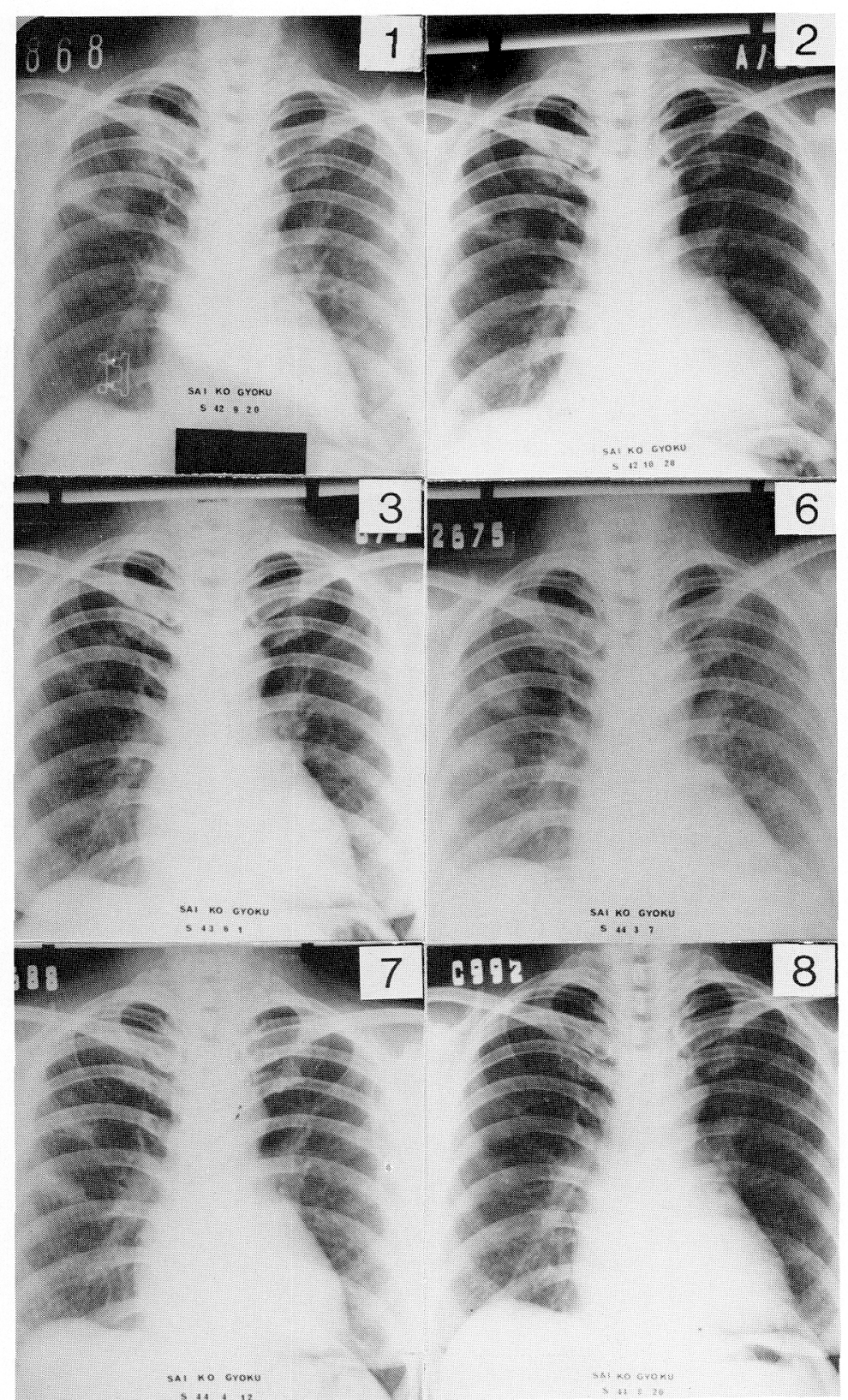

Photo. 1 Chest roentogenogram taken on Sept. 20, 1967.

Two shadows are seen in the right middle lung field.

Photo. 2 Chest roentogenogram taken on Oct. 28, 1967.

Two shadows remain in the same lung field.

Photo. 3 Chest roentogenogram taken on June 1, 1968.

Two shadows remain in the same lung field.

Photo. 6 The chest roentogenogram taken on March 7, 1969, showed two shadows in the same lung field.

Photo. 7 The chest roentogenogram taken on April 12, 1969, showing two shadows in the same lung field.

Photo. 8 The chest roentogenogram taken on August 20, 1969, revealed complete disappearance of the two shadows in the right middle lung field. 
$882(66)$
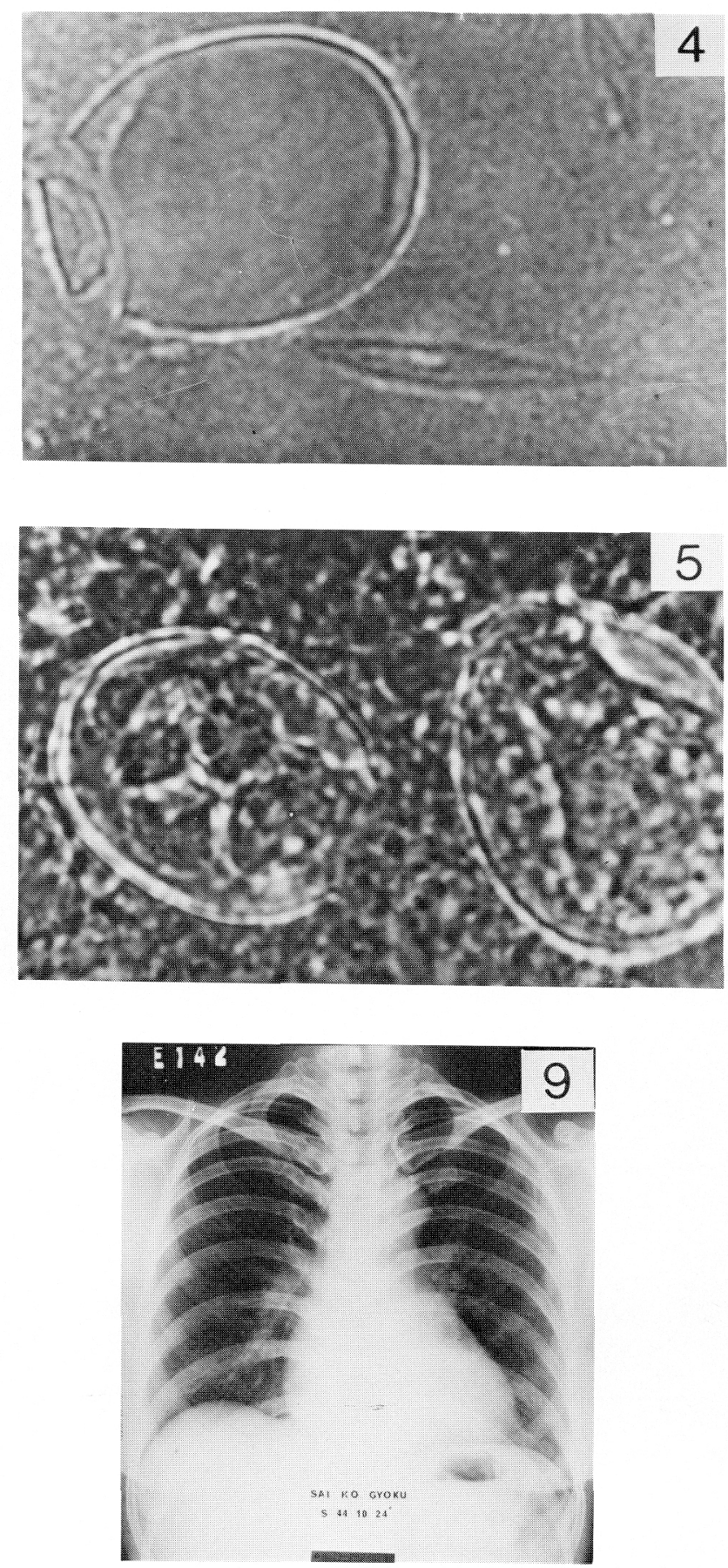

Photo. 4 Egg of the lung flukes with Charcot-Leyden crystal in sputum taken on March 5, 1969.

Photo. 5 Two eggs of the lung fluke in stool taken on March 5, 1969.

Photo. 9 The chest roentogenogram taken on October 24, 1969, showing none of the abnormal shadow. 


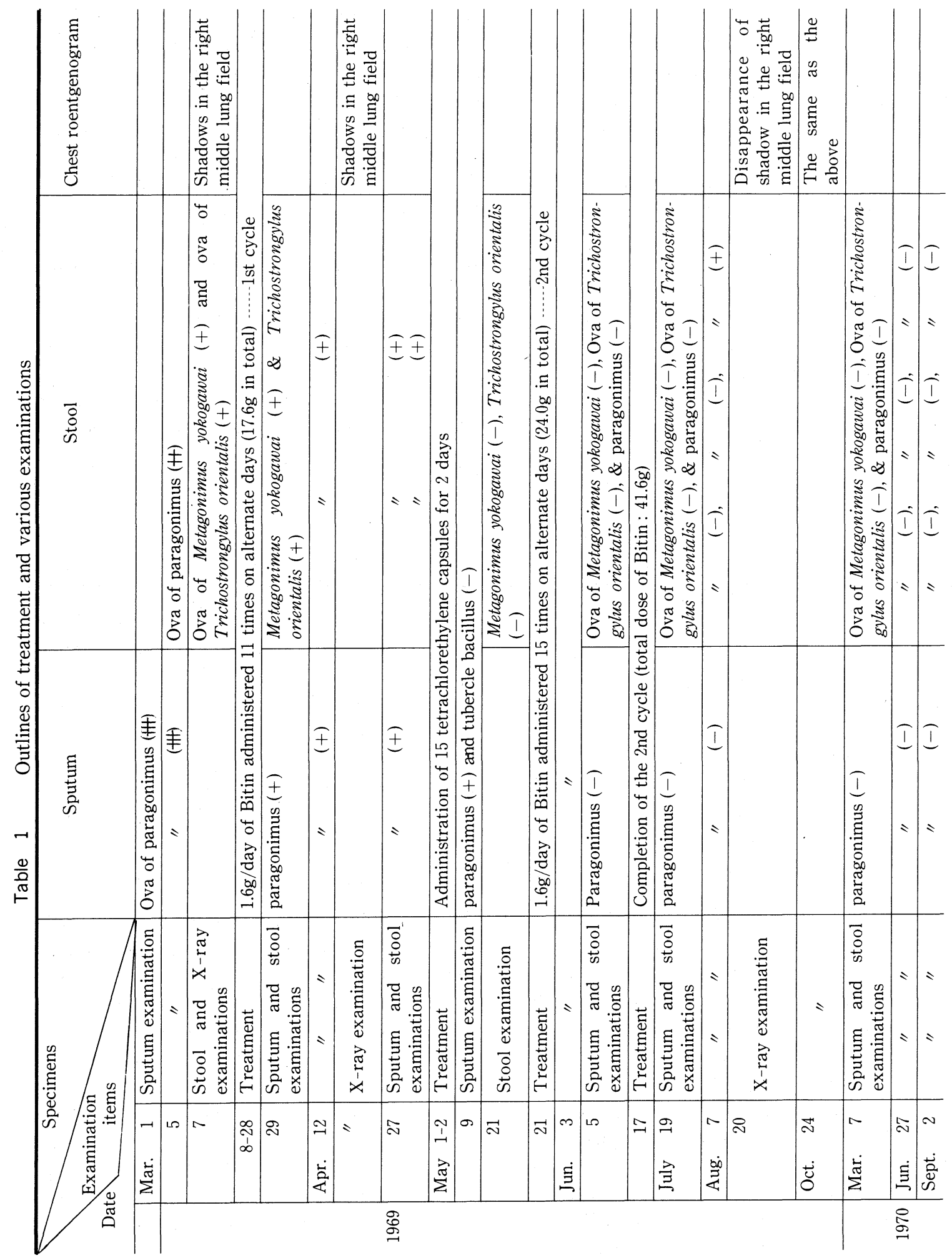


As shown in Table 1, the results of three additional tests of the sputum and stool were positive for ova of paragonimus and other intestinal parasites. Moreover, the chest X-ray film (Photo 7) on April 12 evidently showed persistence of the shadows in the right middle lung field.

Accordingly, each 15 tetrachlorethylene capsules were administered for 2 days in order to drive away intestinal parasites such as Metagonimus yokogawai and Trichostrongylus orientalis at the beginning of May. After 20 days, the stool gave negative tests for ova of both parasites.

After discontinuance of treatment with Bitin for about 1 month, $1.6 \mathrm{~g} /$ day was administered 15 times on alternate days (24.0g in total) as the second cycle. Namely, the total dose of the first and second cycles was $41.6 \mathrm{~g}$.

On July 19 and August 7, sputum and stool specimens gave completely negative tests for the ova of Paragonimus, Metagonimus yokogawai and Trichostrongylus orientalis.

The chest X-ray film taken on August 20 (Photo 8) also revealed complete disappearance of two shadows in the right middle lung field and absence of shadows in any other field. The X-ray film taken on October 24 (Photo 9) also showed no shadows.

The hematological findings of this patient were as shown in Table 2. The number of eosinophils which had increased markedly before treatment decreased almost to normal on August 20, showing efficacy of the treatment.

The ova of paragonimus detected from the sputum of this patient were $38-58 \mu$ in short diameter and $55-78 \mu$ in long diameter.

Table. 2 Findings of hematological examination

\begin{tabular}{|c|c|c|c|c|c|c|c|c|c|c|c|}
\hline \multirow{2}{*}{$\begin{array}{l}\text { Hematological } \\
\text { examination } \\
\text { Date of } \\
\text { examination }\end{array}$} & \multirow{2}{*}{\begin{tabular}{|l|}
$\begin{array}{l}\text { Erythrocyte } \\
\text { sedimentation } \\
\text { rate } \\
\quad(1 \text { hour })\end{array}$ \\
\end{tabular}} & \multicolumn{6}{|c|}{ Blood picture } & \multirow{2}{*}{$\begin{array}{c}\text { Erythrocyte } \\
\text { count }\end{array}$} & \multirow{2}{*}{$\begin{array}{c}\text { Leukocyte } \\
\text { count }\end{array}$} & \multirow{2}{*}{$\begin{array}{c}\text { Hemoglobin } \\
\text { value }\end{array}$} & \multirow{2}{*}{$\begin{array}{c}\text { Hematocrit } \\
\text { value }\end{array}$} \\
\hline & & St. & Seg. & Eos. & Bas. & Ly. & Mon & & & & \\
\hline 1967. 10. 28. & $46 \mathrm{~mm}$ & $4 \%$ & $41 \%$ & $34 \%$ & $0 \%$ & $21 \%$ & $0 \%$ & - & - & - & - \\
\hline 1968. 6. 1. & $12 \mathrm{~mm}$ & 3 & 31 & 18 & 0 & 41 & 7 & - & - & - & - \\
\hline 1969. 3. 15. & - & 8 & 43 & 21 & 0 & 26 & 2 & - & - & - & - \\
\hline 1969. 8. 20. & $\longrightarrow$ & 7 & 37 & 6 & 0 & 49 & 0 & $3,910,000$ & 5,700 & $75 \%$ & $38 \%$ \\
\hline
\end{tabular}

\section{Summary and discussion}

As described above, this patient came to Wakayama Prefecture in Japan from her legal domicile in Korea at the age of 16 years. She visited her native place in Korea after 27 years and stayed there for about 2 months, followed by coming back to the present address. After 2-3 months, she noticed a movable mass in the truncus and visited a hospital because of expectoration of bloody sputum. Pulmonary tuberculosis was diagnosed on the basis of chest $\mathrm{X}$-ray findings, though presence of tubercle bacillus and parasitic ova in the sputum remained unclear and she received antituberculotic therapy.

This patient likes raw freshwater fish by nature. According to her, she ate raw freshwater fish (carp), but did not eat crabs during her stay in Korea.

On March 1, 1969, the author examined the sputum and stool of this patient by the referral and request from her attendant physician and demonstrated many ova of paragonimus, initiating treatment with bithionol. After $17.6 \mathrm{~g}$ of Bitin was administered in the first cycle, $24.0 \mathrm{~g}$ in the second cycle after about 1 month of discontinuance ( $41.6 \mathrm{~g}$ in total). 
According to Yokogawa ${ }^{4,6)}$, sufficient efficacy has been obtained with almost no side effect when $30-50 \mathrm{mg} / \mathrm{kg} /$ day of Bitin is ingested 15 times on alternate days. Satisfactory efficacy could also be obtained in this patient.

According to Yokogawa ${ }^{6}$ ) and Miyazaki ${ }^{5)}$, administration of $40 \mathrm{mg} / \mathrm{kg} / \mathrm{day}$ of Bitin leads to disappearance or reduction of chest X-ray shadows after 1-3 months.

In this patient, sputum cultures became nagative for ova of paragonimus 3 months after the onset of treatment with Bitin (June 5) and both of the two shadows in the right middle lung field disappeared completely after 5 months. Hematological values also returned to normal and complete healing could be obtained by Bitin in this patient.

However, there remains a questionable point. Namely, the patient who had eaten raw freshwater fish (carp), but had not eaten any crabs during her short stay in her native place in Korea manifested symptoms of paragonimiasis within 2-3 months after return to Japan. Since she ate crabs frequently in the present address, it is difficult to determine whether infection occurred in Korea or the present address in Wakayama Prefecture. If there is a possibility that infection may occur around the present address, fact-finding and epidemiological surveys must be carried out in this district. These surveys will be described in another reports ${ }^{8,9}$.

A general research team on paragonimus was organized in 1958 by the science-research-aid fund of the Ministry of Education. According to Miyazaki ${ }^{2}{ }^{2}$ who reported the results of a nationwide survey conducted by this team during 3 years until 1960, distribution of paragonimus was investigated in terms of distribution of its larvae in seaweed crabs. However, since Wakayama Prefecture was not included in this survey, distribution and actual condition of paragonimus remained quite unclear.

More recently, the author carried out a survey on the prevalence of human paragonimiasis in Wakayama Prefecture as reported eleswhere and also made an epidemiological survey on Paragonimus by intradermal test on inhabitants 2 or 3 districts and in-patients of special hospitals for tuberculosis in the prefecture, but there still remain unclear problems to be solved.

In the past, the kind of ova detected in the sputum and stool of this patient was considered probably unrelated to $P$. westermani on the basis of findings such as almost circular shape, thickened part of the eggshell, condition of the egg lid and measurements of short and long diameters, especially the maximum width of the short diameter locating near the center ${ }^{7}$. However, $P$. westermani was found by serological.examination (complement fixation test) of this patient carried out in the Department of Parasitology, Chiba University.

\section{Conclusion}

A woman who was born in Korea had a movable mass in the truncus and bloody sputum. Although she manifested symptoms apparently suggestive of paragonimiasis, pulmonary tuberculosis was suspected on the basis of chest $\mathrm{X}$-ray shadows in the right middle lung field and antituberculotic therapy was performed in spite of non-detection of parasitic ova and tubercle bacillus by sputum examination.

After that, many ova of paragonimus were detected by sputum and stool examinations in the author's laboratory and she was treated with bithionol markedly effective for paragonimiasis. After administration of $41.6 \mathrm{~g}$, ova of paragonimus disappeared completely from the sputum and stool and chest $\mathrm{X}$-ray shadows in the right middle lung field also disappeared completely. Hematological values also returned to normal and complete healing could be obtained. The kind of ova was identified as $P$. westermani by complement fixation test. 


\section{Acknowledgements}

The author would like to thank Dr. Den Sumita, a medical practitioner in Wakayama City, for his referral of a valuable patient and giving an opportunity of study, and Miss Chisato Yamasaki for her technical assistance in various examinations. The author wishes to express his gratitude to Prof. Muneo Yokogawa, Department of Parasitology, School of Medicine, Chiba University, and to Prof. Ichiro Miyazaki, Department of Parasitology, School of Medicine, Kyushu University for their special directions and advices in the field of parasitology.

\section{References}

1) Dohnomae, I., Akamatsu, M., Yamamoto, Y., and Shinno, Y.: Diagnosis of paragonimiasis, especially differential diagnosis from pulmonary tuberculosis. Disease of Chest, 5, 974-986 (1961)

2) Miyazaki, I.: Outline of classification, growth history, and distribution of paragonimus, Disease of Chest, 5, 953-962 (1961)

3 ) Miyazaki, I. : Outline of studies on lung flukes and paragonimiasis. Disease of Chest, 5, 963 -964 (1961)

4) Yokogawa, M. : Pathology, diagnosis, and treatment of paragonimiasis. Disease of Chest, 5, 965-973 (1961)

5 ) Miyazaki, I. : Clinical results of human paragonimiasis with Bitin, The Jap. J. of Clin. and Exper. Medicine, 39, 892-897 (1962)

6 ) Yokogawa, M., Yoshimura, H., Sano, K., Okura, T., Tsuji, M., Iwasaki, M., Hirose, H., and Shigeyasu, M. : Studies on chemotherapy for paragonimiasis (Rep. 2). Clinical results of human paragonimiasis with Bitin. Therapy, 43, 917-924 (1961)

7 ) Sumita, D., Yamasaki, C., and Shirakawa, M.: Paragonimiasis probably unrelated to Paragonimus westermani and relationship between treatment and chest $\mathrm{X}$-ray findings. Jap. J. of Parasitology, 18, 681-682 (1969)

8 ) Shirakawa, M.: Survey and investigations on occurrence of human paragonimiasis in Wakayama Prefecture. J. of Jap. Assoc. of Rural Med. 32, 197-201, 1983.

9 ) Shirakawa, M.: Survey of human paragonimiasis with intradermal test in Wakayama Prefecture. J. of Jap. Assoc. of Rural Med. 32, 874-878, 1983.

\section{人体肺吸虫症の 1 例と, その治療成績}

$$
\text { 白川 充* }
$$

韓国生れの 1 女性が, 軀幹部に移動性の腫瘤と血痰 を来し，明らかに肺吸虫症を疑わせる症状があったに もかかわらず, 検痰によっても寄生虫卵や結核菌は検 出されないままに, 胸部のX線写真の所見で, 右中肺 野の陰影にもとづいて, 肺結核症の疑いのもとに, 抗 結核療法が行なわれていた。

その後, 著者の研究室で検痰と検便を行ない, 多数

\footnotetext{
* 宮崎医科大学医学部衛生学教室
}

の肺吸虫卵を検出し, 肺吸虫症に特効のあるビチオ ノール(ビチン)で治療を行ない, 2 クールの治療（総 投与量 $41.6 \mathrm{~g})$ に上り, 喀痰や糞便中に肺吸虫卵は全 く検出されなくなった。

また胸部の X線写真の所見でも，右中肺野の陰影は 完全に消失し，血液所見も正常に復して，本症を完全 に治癒させることができた。

な搔種については，補体結合反応により，Par agonimus westermani と同定された。 